\title{
AKTIVITAS PENURUNAN GULA DARAH KOMBINASI EKSTRAK DAUN KUMIS KUCING (ORTHOSIPHON ARISTATUS) DAN EKSTRAK DAUN INSULIN (TITHONIA DIVERSIVOLIA) TERHADAP MENCIT (MUS MUSCULUS)
}

\author{
Ragil Dwi Atmojo*, Hanggara Arifian, Arsyik Ibrahim, Rolan Rusli \\ Laboratorium Penelitian dan Pengembangan FARMAKA TROPIS, \\ Fakultas Farmasi, UniversitasMulawarman, Samarinda, Kalimantan Timur. \\ *email: ragildwi21@gmail.com
}

\begin{abstract}
ABSTRAK
Tanaman Kumis Kucing dan Insulin merupakan tanaman yang secara tradisional digunakan secara tunggal sebagai antihiperglikemik. Kandungan polifenol dan flavonoid pada kedua tanaman tersebut diduga mampu memberikan aktivitas sebagai antihiperglikemik. Untuk itu dilakukan penelitian secara ilmiah dengan menguji aktivitas penurunan gula darah dengan mengkombinasikan ektrak daun kumis kucing (Orthosiphon aristatus) dan ekstrak daun insulin (Tithonia diversifolia) terhadap mencit (Mus musculus). Tujuan dari penelitian ini adalah untuk Mengetahui aktivitas penurunan gula darah Mencit (Mus musculus) Ekstrak Etanol Daun Kumis Kucing (Orthosiphon aristatus) dan Ekstrak Etanol Daun Insulin (Tithonia diversivolia). Uji penurunan gula darah dilakukan dengan metode toleransi glukosa oral dan diukur dengan glukometer. Mencit dibagi menjadi 5 kelompok, yaitu kontrol negatif, pembanding glibenklamid, kelompok uji ekstrak kombinasi perbandingan Ekstrak daun insulin $(300 \mathrm{mg} / \mathrm{kgBB})$ :Ekstrak daun Kumis kucing $(750 \mathrm{mg} / \mathrm{kg})$ dengan perbandingan masing-masing 1:1, 2:1 dan 1:2. Data diperoleh dari pemeriksaan kadar glukosa darah pada menit ke 15, 30, 60, 90, 120, 150, 180 dan 210 menit. Pemberian sediaan uji dilakukan setelah diberikan pembebanan sukrosa $5 \mathrm{~g} / \mathrm{kgBB}$. Hasil penelitian menunjukkan bahwa kombinasi ekstrak dengan perbandingan 1:1, 1:2 dan 2:1 memiliki aktifitas dalam menurunkan gula darah dengan dosis 2:1 dapat menurunkan kadar gula darah secara optimum dan efek yang dihasilkan berbeda dengan Glibenklamid.
\end{abstract}

Kata Kunci: Antihiperglikemik, Orthosiphon aristatus, Thitonia diversifolia.

\begin{abstract}
Orthosiphon aristatus and Tithonia diversivolia plants that are traditionally used in the singular as antihiperglikemic. The content of polyphenols and flavonoids in both plants are thought to provide the activity as antihiperglikemik. The purpose of this research is to know the activity of decrease glucose blood of Mice (Mus musculus) using combination of Ethanol extracts of $O$. aristatus and $T$. diversivolia. Mice are divided into five groups, negative control, glibenklamid, Group of test of extract combination with ratio 1:1, 2:1 and 1:2. Data was obtained from the examination of blood glucose levels on the 15, 30,60, 90, 120, 150, 180 and 210 minutes. Combination of extract was given after loading sucrose $5 \mathrm{~g} / \mathrm{kg}$. The results showed that the combination of extracts by comparison 1:1, 1:2 and 2:1 have a activity in decreasing blood sugar with comparison 2:1 can optimum decreasesing blood sugar and result efect different with Glibenclamid.
\end{abstract}

Keywords : Antihiperglycemic, Orthosiphon aristatus, Thitonia diversifolia. 


\section{PENDAHULUAN}

Di Indonesia diabetes melitus dikenal dengan istilah penyakit gula atau kencing manis. Penyakit ini ditandai dengan meningkatnya kadar glukosa darah (hiperglikemia) yang terjadi akibat tubuh kekurangan hormon insulin baik absolut maupun relatif (Dewi, 2014). Penggunaan bahan alam, sebagai tanaman obat cenderung meningkat di era back to nature. Tanaman obat banyak digunakan masyarakat menengah ke bawah terutama dalam upaya preventif, promotif, dan rehabilitas. Sementara itu banyak orang beranggapan bahwa penggunaan tanaman obat relatif lebih aman dibandingkan obat sintesis (Katno dan Pramono, 2003).

Daun insulin merupakan salah satu tumbuhan yang digunakan masyarakat dalam mengatasi diabetes melitus, rebusan daun ini dipercaya berkhasiat dalam mengobati diabetes melitus (Pasaribu, 2015). Metabolit sekunder yang terkandung dalam masing-masing tumbuhan yaitu diantaranya flavonoid, saponin, fenolik, kuinon dan tanin pada tumbuhan kumis kucing (Yulianti et all, 2015), sementara pada tumbuhan insulin terdapat alkaloid, flavonoid, saponin, fenolik dan steroid (Darmawi et all, 20015)

Di masyarakat penggunaan terhadap dua atau beberapa tanaman yang memiliki khasiat yang sama dipadukan atau dikombinasikan secara bersamaan dengan tujuan untuk mendapatkan hasil atau efek yang lebih baik dibandingkan penggunaan secara tunggal. Untuk memberikan dasar bukti manfaatnya, perlu dilakukan penelitian terhadap efek penurunan kadar glukosa darah dari kedua ekstrak tanaman tersebut. Tujuan dari penelitian ini adalah Mengetahui aktivitas penurunan gula darah Mencit (Mus musculus) Ekstrak Etanol Daun Kumis Kucing (Orthosiphon aristatus) dan Ekstrak Etanol Daun Insulin (Tithonia diversivolia), Mengetahui perbandingan konsentrasi kombinasi Ekstrak Etanol Daun Kumis Kucing (Orthosiphon aristatus) dan Ekstrak Etanol Daun Insulin (Tithonia diversivolia) terbaik yang dapat menurunkan kadar gula darah mencit (Mus musculus) serta Mengetahui potensi kombinasi Ekstrak Etanol Daun Kumis Kucing (Orthosiphon aristatus) dan Ekstrak Etanol Daun Insulin (Tithonia diversivolia) menurunkan kadar gula darah dibandingkan dengan obat Glibenklamid.

\section{METODOLOGI PENELITIAN}

Pengujian aktivitas antihiperglikemik dilakukan dengan menggunakan Ekstrak Etanol Daun Kumis Kucing (Orthosiphon aristatus) dan Ekstrak Etanol Daun Insulin (Tithonia diversivolia) dengan dosis masing-masing $300 \mathrm{mg} / \mathrm{kgBB}$ (Astuti, 2012) dan $750 \mathrm{mg} / \mathrm{kgBB}$ (Rosyidi, 2014). Dengan adanya kedua dosis tersebut maka dibuat dosis kombinasi yaitu 1:1, 2:1 dan 1:2 (ekstrak Insulin:ekstrak kumis kucing) dimana perbandingan 1:1 artinya adalah perbandingan dosis antara ekstrak insulin dan ekstrak kumis kucing adalah sama dimana dosis yang digunakan adalah hasil konversi dosis ke hewan uji, sementara perbandingan 1:2 artinya perbandingan dosis yang digunakan pada ekstrak insulin adalah 1 kali dosis awal sementara pada ekstrak kumis kucing adalah 2 kali dari dosis awal yang masing-masing dosis telah dikonversikan ke hewan uji, begitu pula dengan dosis kombinasi 2:1 yaitu dosis ekstrak insulin adalah 2 kali dari dosis awal sementara dosis ekstrak kumis kucing 1 kali dari dosis awal. Penelitian dilakukan terhadap 25 ekor mencit jantan galur Swiss Webster yang kemudian dikelompokkan menjadi 5 kelompok secara acak yang terdiri dari kelompok kontrol negatif, kelompok kontrol positif serta 3 kelompok ekstrak uji masing-masing uji 1:1, 2:1 dan 1:2 yang terdiri dari 5 ekor setiap kelompok. Sebelum dilakukan pembebanan glukosa, dilakukan pengecekan kadar glukosa darah awal pada setiap kelompok. Kemudian dilakukan induksi pembebanan glukosa akut $5 \mathrm{~g} / \mathrm{kgBB}$ dengan menggunakan sukrosa (gula dapur) yang ditunggu selama 15 menit dan kemudian dilakukan pengukuran kadar glukosa darah pada menit ke 15, 30, 60, 90, 120, 150, 180 dan 210 menit. Pengukuran kadar glukosa dilakukan menggunakan glukometer. Selanjutnya dilakukan 
perhitungan data statistika dengan metode ANAVA antara kelompok uji dan kelompok kontrol negatif dan uji lanjut dengan Duncan untuk melihat kebermaknaan penurunan kadar glukosa darah antar kelompok yaitu kelompok kontrol negatif, kelompok kontrol positif dan kelompok uji dengan perbandingan 1:1, 2:1 dan 1:2.

\section{PEMBAHASAN}

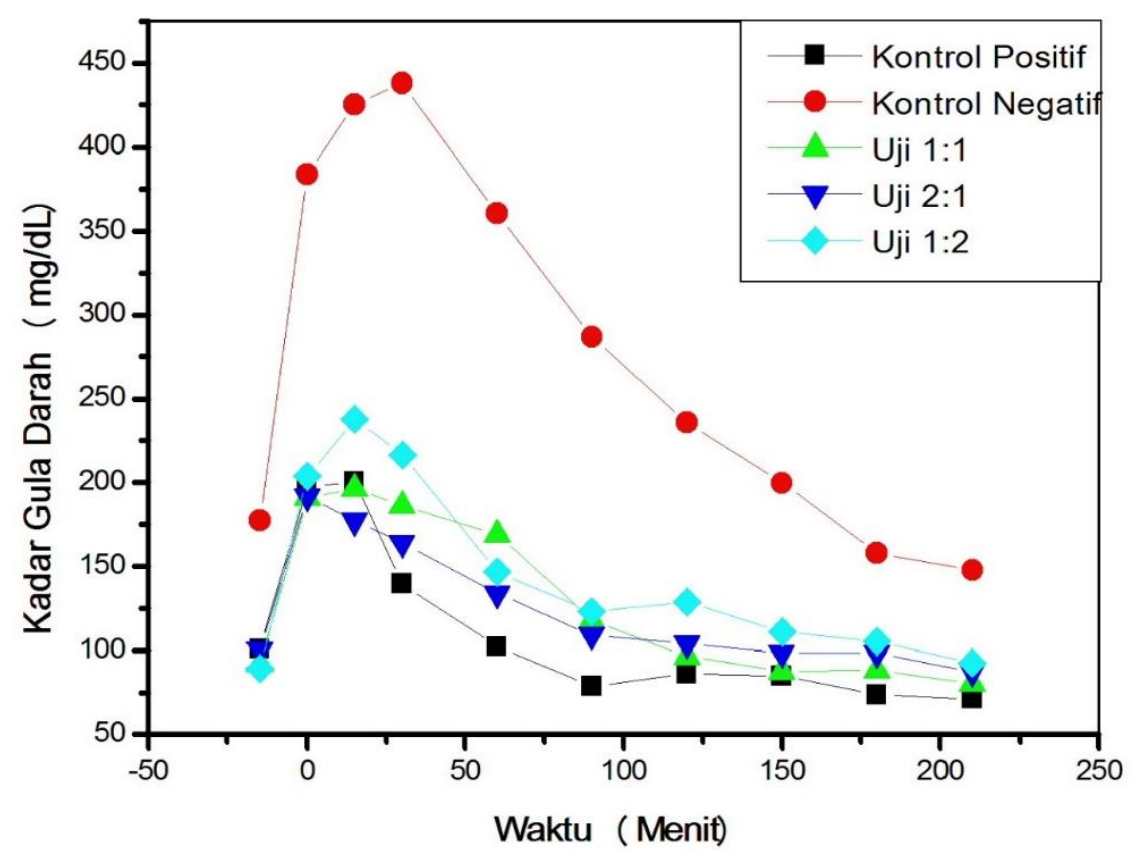

Gambar 1. Rata-Rata Penurunan Kadar Glukosa Darah Mencit (mg/dL) Per Waktu Pengambilan. Kadar gula darah waktu 0 menit adalah kadar gula darah saat 15 menit setelah pemberian beban glukosa (kadar beban glukosa)

\section{Aktivitas Penurunan Kadar Glukosa Darah Kombinasi Ekstrak Uji}

Penelitian ini menggunakan metode Uji Toleransi Glukosa (OGTT) yaitu dengan memberikan induksi beban glukosa dengan konsentrasi larutan glukosa yang digunakan adalah $50 \%$ atau setara dengan $5 \mathrm{~g} / \mathrm{kgBB}$. Mencit normal induksi hiperglikemia dilakukan dengan pemberian glukosa dosis tinggi ( 5 gram $/ \mathrm{Kg} \mathrm{BB}$ ) yang akan meningkatkan kadar glukosa darah yang sifatnya sementara. Metode ini bertujuan untuk mengetahui kemampuan tubuh mentoleransi pemberian larutan glukosa sehingga dapat diketahui adanya pengaruh pemberian bahan uji dengan melihat kurva toleransi glukosa. Berdasarkan hasil yang diperoleh menunjukkan bahwa pemberian beban glukosa mampu memberikan efek kenaikan glukosa darah setelah 15 menit awal pasca pemberian glukosa dan mulai untuk dieliminasi tubuh untuk diubah menjadi energi didalam sel pada menit ke 30, pemberian perlakuan pada ekstrak uji dan kontrol positif terbukti mampu menurunkan kadar glukosa darah menuju normal lebih cepat dibandingkan dengan kontrol negatif. Glibenklamid merupakan obat antidiabetik oral dengan bekerja merangsang sekresi hormon insulin dari granul sel-sel $\beta$ Langerhans pankreas (Syah et all, 2015).

Perbandingan rata-rata penurunan glukosa darah antara tiap perlakuan kelompok uji yang dibandingkan dengan kelompok kontrol, baik negatif maupun positif dapat dilihat pada Gambar 1. Berdasarkan presentase penurunan kadar glukosa darah antara penggunaan secara tunggal esktrak etanol kumis kucing dan ekstrak insulin diperoleh hasil presentase masing- 
masing sebesar 37,09\% (Rosyidi, 2014) dan 29,04\% (Astuti, 2012). Pada gambar 1 menunjukkan kadar glukosa darah setelah pemberian beban glukosa sebanyak $5 \mathrm{~g} / \mathrm{kg} \mathrm{BB}$ menunjukkan peningkatan kadar glukosa darah. Pendekatan klinis yang dilakukan pada hewan coba yaitu pengkategorian terjadinya hiperglikemik atau peningkatan kadar glukosa darah melebihi normal (kadar glukosa darah $\geq 150 \mathrm{mg} / \mathrm{dL}$ ) dimana kadar glukosa darah normal pada mencit yang berumur 10 minggu adalah $61-130 \mathrm{mg} / \mathrm{dL}$ (Grant et al, 2012). Terjadinya kenaikan atau penurunan kadar glukosa darah selama pengujian dapat disebabkan oleh faktor fisiologi (fungsi dari organ tubuh) hewan uji yang menyebabkan efek obat dalam hal ini kombinasi dari kedua ekstrak tersebut ataupun glibenklamid (Ayu, 2014).

Berdasarkan Gambar 1, kombinasi dari ekstrak uji memiliki aktivitas dalam menurunkan kadar glukosa darah, hal ini dikarenakan hampir semua variasi dosis ekstrak uji dapat menurunkan kadar glukosa darah, namun yang menurunkan kadar glukosa lebih baik adalah ekstrak uji dengan perbandingan 1:1 dan 2:1 (esktrak daun insulin:ekstrak daun kumis kucing) sementara pada ekstrak uji 1:2 juga dapat menurunkan kadar glukosa darah namun tidak sebaik ekstrak uji dengan perbandingan 1:1 dan 2:1. Metabolit sekunder yang terkandung dalam masing-masing tumbuhan yaitu diantaranya flavonoid, saponin, fenolik, kuinon dan tanin pada tumbuhan kumis kucing (Yulianti et all, 2015), sementara pada tumbuhan insulin terdapat alkaloid, flavonoid, saponin, fenolik dan steroid (Darmawi et all, 20015) sehingga diduga memiliki aktivitas penurunan glukosa darah dengan mekanisme yaitu Senyawa fenol memiliki keampuan dalam meningkatan sekresi insulin, dan meningkatan fungsi dari sel $\beta$ pankreas sehingga dapat menimbulkan efek hipoglikemik pada mencit. Sedangkan flavanoid dan tannin memiliki aktivitas penurunan gula darah dengan cara penghambatan kerja $\alpha$-glukosidase sehingga penyerapan gula dan laju peningkatan gula pada sistem pencernaan masih tidak terlalu tinggi (Yuda et all, 2015). Menurut Singh et al (2011), mekanisme saponin sama seperti obat hipoglikemia oral golongan sulfonilurea. Mekanisme kerjanya dengan menghambat channel K-ATP sehingga aliran kalium $(\mathrm{K}+)$ keluar sel terganggu. Akibatnya terjadi depolarisasi membran sel $\beta$ pankreas, sehingga channel $\mathrm{Ca}^{2+}$-ATPase terbuka dan ion kalsium $\left(\mathrm{Ca}^{2+}\right)$ mengalir masuk ke sitoplasma. Keberadaan ion kalsium tersebut mengaktifkan enzim kalmodulin dalam sel sehingga terjadi eksositosis insulin dari versikel untuk diekskresikan keluar sel.

Berdasarkan kurva kadar gula darah pada gambar 1, dihitung nilai luasan area di bawah kurva (AUC0-210). AUC (Area Under Curve) total yang menggambarkan penurunan kadar gula darah secara keseluruhan pada masing-masing kelompok. AUC (Area Under Curve) berfungsi untuk menghitung kadar gula darah mencit uji jantan pada setiap penurunan kadar gula darah tiap menit. Data hasil perhitungan dapat dilihat pada tabel 1.

Tabel 1. Nilai Luasan Area Dibawah Kurva $\left(\mathrm{AUC}_{\text {total }}\right)$ pada Berbagai Dosis Perlakuan

\begin{tabular}{cccccc}
\hline Perlakuan & $\begin{array}{c}\text { Kontrol } \\
+\end{array}$ & $\begin{array}{c}\text { Kontrol } \\
-\end{array}$ & Uji 1:1 & Uji 2:1 & Uji 1:2 \\
\hline $\begin{array}{c}\text { Nilai AUC } \\
\text { total }\end{array}$ & 21987 & 59567 & 27149 & 26243 & 30566 \\
$\begin{array}{c}\text { (mg.menit/dL) } \\
\text { \%PKGD }\end{array}$ & 63,089 & - & 54,423 & 55,944 & 48,686 \\
\hline
\end{tabular}

Nilai AUC (Area Under Curve) yang terkecil ditunjukkan oleh kelompok kontrol positif yaitu dengan nilai AUC total $21987 \mathrm{mg} / \mathrm{dL}$ menit yang berarti pemberian kontrol positif dapat menurunkan kadar gula darah. Nilai AUC total terbesar dimiliki oleh kontrol negatif yaitu $59567 \mathrm{mg} / \mathrm{dL}$ menit yang hanya diberikan NaCMC 0,5\%, kemudian ekstrak uji 
1:1, 2:1 dan 1:2 dengan nilai AUC total masing-masing 27149, 26243 dan $30566 \mathrm{mg} / \mathrm{dL}$ menit lebih rendah dibandingkan dengan nilai AUC total kelompok kontrol negatif yang berarti diasumsikan bahwa pemberian perlakuan ekstrak uji memiliki efek dalam menurunkan kadar gula darah. Pada kelompok uji 2:1 memiliki nilai AUC total yang lebih rendah dibandingkan dengan kelompok uji 1:1 dan 1:2 tetapi lebih tinggi dibandingkan dengan kontrol positif. Berdasarkan nilai persen penurunan kadar gula darah pada kelompok kontrol positif, uji 1:1, uji 2:1 dan 1:2 diperoleh nilai masing-masing 63,089\%, 54,423\%, $55,944 \%$ dan 48,686\%. Diketahui kelompok kontrol positif memiliki persen penurunan kadar gula darah yang paling besar dibandingkan kelompok uji. Sementara uji 2:1 adalah kelompok uji yang memiliki persen penurunan kadar gula darah yang paling besar diantara kelompok uji.

Data $\left(\mathrm{AUC}_{0-210}\right)$ pada tiga variasi kombinasi uji dan kontrol negatif kemudian dianalisis ANAVA. Analisis ANAVA digunakan untuk mengetahui ada atau tidaknya pengaruh pada perlakuan variasi kombinasi ekstrak uji dan kontrol negatif terhadap penurunan kadar gula darah. Hasil analisis ANAVA diperoleh nilai Sig $(0,000)(<p=0,05)$ yang berarti adanya perbedaan antara penurunan gula darah pada kombinasi ekstrak uji dengan kontrol negatif. Dilakukan uji Least Significant Difference (LSD) menggunakan taraf $95 \%$ untuk mengetahui kelompok perlakuan yang berbeda bermakna.

Tabel 2. Hasil Uji LSD (AUC ${ }_{0-210}$ ) Antar Kelompok Dengan Taraf Kepercayaan 95\%

\begin{tabular}{lll}
\hline Antar Kelompok Perlaakuan & Nilai P & Keterangan \\
\hline Kontrol Negatif - Kontrol Positif & 0,000 & Berbeda Bermakna \\
Kontrol Negatif - Uji 1:1 & 0,000 & Berbeda Bermakna \\
Kontrol Negatif - Uji $2: 1$ & 0,000 & Berbeda Bermakna \\
Kontrol Negatif - Uji 1:2 & 0,001 & Berbeda Bermakna \\
Kontrol Positif - Uji 1:1 & 0,529 & Berbeda Tidak Bermakna \\
Kontrol Positif - Uji 2:1 & 0,626 & Berbeda Tidak Bermakna \\
Kontrol Positif - Uji 1:2 & 0,305 & Berbeda Tidak Bermakna \\
Uji 1:1 - Uji 2:1 & 0,886 & Berbeda Tidak Bermakna \\
Uji 1:1 - Uji 1:2 & 0,688 & Berbeda Tidak Bermakna \\
Uji 2:1 - Uji 1:2 & 0,586 & Berbeda Tidak Bermakna \\
\hline
\end{tabular}

*Keterangan: Jika p-value < 0,05 ada perbedaan bermakna; Jika p-value $>0,05$ tidak ada perbedaan bermakna

Berdasarkan tabel 2 diketahui bahwa kontrol negatif, Uji 1:1, Uji 2:1 dan Uji 1:2 menunjukkan nilai signifikan yaitu 0,000, 0,000 dan 0,001 $(\mathrm{p}<0,05)$ berbeda bermakna artinya dosis uji memiliki efek menurunkan kadar glikosa darah. Kelompok kontrol positif, uji 1:1, uji 2:1 dan uji 1:2, menunjukkan nilai signifikan yaitu 0,529, 0,626 dan 0,305 $(\mathrm{p}>0,05)$ ada perbedaan tidak bermakna artinya dosis uji memiliki efek menurunkan kadar gula darah namun kelompok kontrol positif memiliki efek yang lebih baik dibandingkan kelompok uji. Berdasarkan hasil dari nilai $\left(\mathrm{AUC}_{\text {total }}\right)$ tabel 1 kelompok uji terkecil diketahui kombinasi ekstrak etanol insulin : kumis kucing dapat menurunkan kadar gula darah adalah dosis uji kombinasi 2:1. Untuk mengetahui perbandingan efek penurunan kadar gula darah dosis optimal dengan Glibenkalmid dapat dilakukan dengan uji t. Hal ini untuk mengetahui potensi kombinasi dari ektrak uji dengan debagai penurun kadar gula darah.adapun hasil data pengujian penurunan kadar gula darah dosis optimum dapat dilihat pada tabel 1.

Hasil analisis uji t ekstrak uji kombinasi 2:1 sebagai dosis optimum dengan kontrol positif glibenklamid diperoleh nilai Sig 0,013 dimana nilai Sig < 0,05 maka, uji kombinasi 
2:1 terdapat perbedaan yang signifikan dalam menurunkan kadar gula darah dibandingkan dengan glibenklamid sehingga dapat dikatan memiliki efek yang berbeda dengan kontrol positif yaitu kontrol positif lebih baik dibandingkan dengan ekstrak uji 2:1.

\section{KESIMPULAN}

Pengujian aktivitas antihiperglikemik dengan dosis kombinasi perbandingan 1:1, 2:1 dan 1:2 memiliki aktivitas dalam menurunkan kadar glukosa darah mencit, dengan dosis uji 2:1 sebagai kelompok uji dengan penurunan kadar glukosa yang lebih baik dan memiliki efek yang berbeda dengan pembanding Glibenklamid.

\section{DAFTAR PUSTAKA}

Astuti, Vicoria Cyntia Yogya. 2012. Pengaruh Pemberian Ekstrak Daun Kumis Kucing (Orthosiphon aristatus) Terhadap Penurunan Kadar Glukosa Darah Tikus Wistar Yang Diinduksi. Skripsi Penelitian. Universitas Dipenogoro akultas Kedokteran.

Ayu, Rezchy Dhamuri, Fatimawali dan Citraningtyas Gayatri. 2014. Uji Efektivitas Penurunan Kadar Gula Darah Ekstrak Etanol Daun Sendok (Plantago major L.) pada Tikus Putih Jantan Galur Wistar (Rattus norvegicus) yang Diinduksi Sukrosa. Jurnal Ilmiah Farmasi UNSRAT vol. 3 No. 2

Darmawi, Ary Rizki, Saleh Chairul dan Kartika Rudi. 2015. Aktivitas Antihiperglikemik Dari Ekstrak Etanol Dan n-Heksana Daun Kembang Bulan [Tithonia diversifolia A.Gray] Pada Tikus Putih Jantan. Jurnal Kimia Mulawarman. Volume 12 Nomor 2

Dewi, Yesy Febnic. 2014. Efektifitas Ekstrak Daun Sirih Merah (Piper crocatum) Terhadap Penurunan Kadar Glukosa Darah Tikus Putih Jantan (Rattus novergicus) Yang Di Induksi Aloksan. Buletin Veteriner Udayana Vol. 6 No. 1 ISSN : 2085-2495

Grant, Christian W., Shane K Duclos, Catherine M Moran-Paul, Barak Yahalom, Rebecca S Tirabassi, Guillermo Arreaza-Rubin, Lisa M Spain, and Dennis L Guberski. 2014. Development of Standardized Insulin Treatment Protocols for Spontaneous Rodent Models of Type 1 Diabetes. American Association for Laboratory Animal Science. Volume 62 No 5.

Katno dan Pramono, S., 2003, Tingkat Manfaat dan Keamanan Tanaman Obat dan Tanaman Obat Tradisional. Balai Penerbit FKUI. Jakarta.

Pasaribu, Ronald, Hutahaean Salomo dan Ilyas Syafruddin. 2015. Uji Antihiperglikemia Ekstrak Etanol Daun Kembang Bulan (Tithonia diversifolia) Pada Mencit (Mus musculus) Yang Diinduksi Diabetes Dengan Aloksan. Jurnal Biosains. Volume 1 Nomor 2

Rosyidi, Candra Achmad Hanif. 2014. Efek Ekstrak Daun Insulin Terhadap Kadar Glukosa Darah, Berat Badan dan Kadar Trigliserida Pada Tikus Diabetes strain Sprague dawley Yang Diinduksi Aloksan. Skripsi Penelitian. Universitas Islam Negeri Syarif Hidayatullah.

Singh J, Cumming E, Manoharan G, Adeghate E.2011, Medicinal Chemistry of the AntiDiabetic Effects of actions. The Open Momordica charantia: Active constituents and modes of Medicinal Chemistry. Journal. 2011; 5 (2):70-77

Syah, Muhammad Ilham, Suwendar dan Mulqie Lanny. 2015. Uji Aktivitas Antidiabetes Ekstrak Etanol Daun Mangga Arumansi (Mangifera indica L.) pada Mencit Swiss Webster Jantang dengan Metode Tes Toleransi Glukosa Oral (OGTT). Prosiding Penelitian SPeSIA Unisba. ISSN 2460-6472

Yuda, Anak Agung Gede Prawira, Rusli Rolan dan Ibrahim Arsyik. Kandungan Metabolit Sekunder dan Efek Penurunan Glukosa Darah Ekstrak Biji Rambutan (Nephelium Lappaceum L) Pada Mencit (Mus Musculus). Jurnal Sains dan Kesehatan. 2015. Vol 1. No 3. 120-125. DOI: https://doi.org/10.25026/jsk.v1i3.28 
Yulianti, Rika, Nugraha Damas Anjar dan Nurdianti Lusi. 2015. Formulasi Sediaan Sabun Mandi Cair Ekstrak Daun Kumis Kucing (Orthosiphon Aristatus (Bl) Miq.). KARTIKA-JURNAL ILMIAH FARMASI Vol. 3 No. 2. p-ISSN 2354-6565 / e-ISSN 2502-3438 